\title{
Enzyme Activities at Varied Soil Organic Carbon Gradients under Different Land Use Systems of Hassan District in Karnataka, India
}

\author{
Sharan Bhoopal Reddy ${ }^{1^{*}}$, M. S. Nagaraja ${ }^{2}$, B. C. Mallesha ${ }^{3}$ and G. G. Kadalli ${ }^{4}$ \\ ${ }^{1}$ Department of Soil Science and Agricultural Chemistry, Agriculture College, \\ Bheemarayanagudi-585287, Karnataka, India \\ ${ }^{2}$ Department of Soil Science and Agricultural Chemistry, UHS, \\ Bagalkot - 587102, Karnataka, India \\ ${ }^{3}$ Department of Agricultural Microbiology, UAS, GKVK, \\ Bengaluru- 560065, Karnataka, India \\ ${ }^{4}$ Department of Soil Science and Agricultural Chemistry, College of Agriculture, \\ Hassan-573225, Karnataka, India \\ *Corresponding author
}

\section{A B S T R A C T}

Most of the biological processes in any soil proceed through enzyme regulated processes. Activities of soil enzymes indicate the soil biological health and it has significant impact on soil fertility improvement. The soil samples from major land uses systems viz., forests (both natural and manmade), coffee, mulberry, coconut, vegetable, potato and paddy land uses systems, were analyzed for soil organic carbon (SOC) and categorized as low $(<0.5 \%)$, medium $(0.5-0.75 \%)$ and high $(>0.75 \%)$ SOC soils. Similar soil samples were analyzed for biological properties i.e, soil enzyme activities for each category. Dehydrogenase and urease activity were observed higher in soils with higher organic matter status, with trend as low SOC $<$ medium SOC $<$ high SOC. And similar trend was observed for acid and alkaline phosphatase activities.

\section{Introduction}

Soil organic matter is a source of essential plant nutrients and acts as a source of food for soil organisms (Woomer et al., 1994; Tan, 2010). The energy requirements of micro and macro organisms, other than autotrophs and chemotrophs, present in the soil are largely met by the organic matter added and the native soil organic matter (Monisa and Tahir, 2018). Soil enzyme activity estimates are often used as indices of microbial activity and soil fertility (Vaughan and Malcolm, 1985; Gianfreda and Bollag, 1996; Ranjith et al., 
2015). With this importance the soil organic matter in maintenance of soil biological status, samples from different soil organic carbon (SOC) category were analyzed for soil enzyme activities to know the influence of SOC.

\section{Materials and Methods}

Fifteen surface soil samples (0-15 cm depth) from different land use systems viz., forests (both natural and manmade), coffee, mulberry, coconut, vegetable, potato and paddy land uses systems, in Hassan district (Karnataka) were analyzed for soil organic carbon and categorized as low ( $<0.5 \%)$, medium $(0.5-0.75 \%)$ and high $(>0.75 \%)$ SOC soils. Then three samples each from low, medium and high SOC category were analyzed for soil biological properties such as enzyme activities by following standard procedures viz., dehydrogenase (Casida et al., 1964), urease (Watts and Crisp, 1954) and phosphatase (acid and alkaline) activities (Tabatabai and Bremer, 1969).

\section{Results and Discussion}

All biochemical activities in soil proceed through enzyme regulated processes and thus, soil enzyme activities can also be used as an index of soil quality. The data pertaining to enzyme activities were presented in Table 1 and 2.

\section{Dehydrogenase and urease activity}

The dehydrogenase activity, an index of biological activity, was measured by measuring the red colored TPF formed from TTC reduction. The quantity of TPF formed ranged from $22.4 \mu \mathrm{g} \mathrm{g}^{-1}$ soil $24 \mathrm{~h}^{-1}$ in potato soils with low SOC to $36.5 \mu \mathrm{g} \mathrm{g}^{-1}$ soil $24 \mathrm{~h}^{-1}$ in coffee plantations with high SOC, indicating least dehydrogenase activity in potato and highest in coffee soils. Agricultural land use systems with high organic matter inputs such as coffee and mulberry recorded higher dehydrogenase activities (Fig. 1).

Urease activity, as expressed by the quantity of urea hydrolyzed, ranged from 56.6 to 76.8 $\mu \mathrm{g} \mathrm{g}^{-1} \mathrm{~h}^{-1}$. Highest urease activity was recorded in coffee plantations $(76.8 \mu \mathrm{g}$ urea hydrolyzed $\mathrm{g}^{-1} \mathrm{~h}^{-1}$ ) while, potato plots were seen with least urease activity $(56.6 \mu \mathrm{g}$ urea hydrolyzed $\mathrm{g}^{-1} \mathrm{~h}^{-1}$ ). Urease enzyme was more active in high biomass turnover systems such as coffee and mulberry plantations.

\section{Acid and alkaline phosphatase activity}

Acid and alkaline phosphatase enzyme activities were measured by quantifying yellow colored p-Nitrophenol (PNP) compound formed from p-Nitrophenol phosphate (PNP-P). The acid phosphatase activity was found higher (37.5 to $43.4 \mu \mathrm{g}$ PNP $\mathrm{g}^{-1} \mathrm{~h}^{-1}$ ) in natural and manmade forests and coffee plantations. However, agricultural systems recorded lower acid phosphatase values (31.3 to $39.1 \mu \mathrm{g}$ PNP g $\mathrm{g}^{-1} \mathrm{~h}^{-1}$ ). The alkaline phosphatase activity was also similar to that of acid phosphatase. However, mulberry soils recorded higher alkaline phosphatase activities among agricultural systems.

\section{Dehydrogenase and urease activity}

The dehydrogenase enzyme activity was higher in tree based land use systems while, its activity was found less in agricultural systems. Highest activity was observed in coffee soils with high SOC, while it was least in soils of coconut plantations and vegetable fields. Similar observations on higher dehydrogenase activity in grasslands and forests are reported by Tiwari and others (1988). Among agricultural systems, mulberry soils recorded higher dehydrogenase activity. Many authors have reported similar observations of higher dehydrogenase activity in forest soils (Ajwa et al., 1998; Nagaraja et 
al., 2018) and lesser activity in agricultural soils (Nagaraja et al., 1997; Vidya et al., 2001; Rajeev et. al., 2015). In similar situations, variations in dehydrogenase activities were observed and they were found related to soil organic- $\mathrm{C}$ and soil microbial biomass (Martens et al., 1992; Ranjith et al., 2015; Nagaraja et al., 2018). Thus, the addition of organic matter is important in maintaining higher dehydrogenase activities.

Urease activity in different land use systems indicated that the application of organic matter is important in maintaining its activity. Variations in urease activity may be related to vegetation types, quantity of organic residues added and the soil organic matter content (Pacholy and Rice, 1973). Production of higher amounts of urea based compounds in forest soils and addition of nitrogen fertilizers in mulberry and coffee soils might have enhanced urease activity. In other words, the agricultural systems receiving nitrogenous fertilizers with sufficient amounts of organic manures are likely to maintain higher urease activities (Singaram and Kamalakumari, 1995). Similar results of higher urease activity are reported in forests (Vinutha, 2005) and agricultural soils (Siddaramappa and Rao, 1971). Both urease and dehydrogenase were found higher in soils with high SOC contents and they declined with decrease in soil organic matter content. Thus, the maintenance of soil organic matter appears to be very important for both the enzymes.

Table.1 Dehydrogenase and urease activities in soils of different land use systems

\begin{tabular}{|c|c|c|c|c|c|c|}
\hline \multirow[t]{2}{*}{ Land use system } & \multicolumn{3}{|c|}{$\begin{array}{l}\text { Dehydrogenase in soils with } \\
\quad\left(\mu \mathrm{g} \text { of TPF } \mathrm{g}^{-1} 24 \mathrm{~h}^{-1}\right)\end{array}$} & \multicolumn{3}{|c|}{$\begin{array}{c}\text { Urease in soils with } \\
\left(\mu \mathrm{g} \text { urea hydrolyzed } \mathrm{g}^{-1} \mathrm{~h}^{-1}\right)\end{array}$} \\
\hline & $\begin{array}{l}\text { Low } \\
\text { SOC }\end{array}$ & $\begin{array}{l}\text { Medium } \\
\text { SOC }\end{array}$ & $\begin{array}{l}\text { High } \\
\text { SOC }\end{array}$ & $\begin{array}{l}\text { Low } \\
\text { SOC }\end{array}$ & $\begin{array}{l}\text { Medium } \\
\text { SOC }\end{array}$ & $\begin{array}{l}\text { High } \\
\text { SOC }\end{array}$ \\
\hline Natural forests & - & 36.1 & 37.2 & - & 64.8 & 66.6 \\
\hline Manmade forests & 31.2 & 33.2 & 34.5 & 64.4 & 65.8 & 67.2 \\
\hline Coffee plantations & 36.0 & 36.4 & 36.5 & 75.8 & 76.1 & 76.8 \\
\hline Mulberry fields & 34.1 & 35.3 & 36.1 & 69.7 & 72.9 & 73.0 \\
\hline Coconut plantations & 23.4 & 24.2 & - & 60.2 & 62.4 & - \\
\hline Potato plots & 22.4 & 23.5 & 24.8 & 56.6 & 57.8 & 58.2 \\
\hline Paddy fields & 26.8 & 27.2 & 27.5 & 61.3 & 62.7 & 63.9 \\
\hline Vegetable fields & 23.9 & 24.7 & 25.4 & 66.8 & 67.3 & 68.0 \\
\hline
\end{tabular}

Note: Categories of low, medium and high SOC soils are based on $<0.50 \%, 0.50-0.75 \%$ and $>0.75 \%$ Soil organic$\mathrm{C}$ respectively; Blank cells indicate that there was no representative soil sample in that category $\mathrm{TPF}$ - Triphenyl formazan formed from Triphenyl tetrazolium chloride (TTC) 
Table.2 Acid and alkaline phosphatase activities in soils of different land use systems

\begin{tabular}{|c|c|c|c|c|c|c|}
\hline \multirow[t]{2}{*}{ Land use system } & \multicolumn{3}{|c|}{$\begin{array}{c}\text { Acid phosphatase in soils with } \\
\left(\mu \mathrm{g} \text { PNP } \mathrm{g}^{-1} \mathrm{~h}^{-1}\right)\end{array}$} & \multicolumn{3}{|c|}{$\begin{array}{l}\text { Alkaline phosphatase in soils with } \\
\left(\mu \mathrm{g} \text { PNP } \mathrm{g}^{-1} \mathrm{~h}^{-1}\right)\end{array}$} \\
\hline & $\begin{array}{l}\text { Low } \\
\text { SOC }\end{array}$ & $\begin{array}{l}\text { Medium } \\
\text { SOC }\end{array}$ & High SOC & Low SOC & $\begin{array}{l}\text { Medium } \\
\text { SOC }\end{array}$ & High SOC \\
\hline Natural forests & - & 41.5 & 43.4 & - & 17.4 & 19.3 \\
\hline Manmade forests & 37.5 & 38.2 & 38.6 & 16.1 & 16.3 & 18.5 \\
\hline Coffee plantations & 40.1 & 40.4 & 41.2 & 17.2 & 17.5 & 20.1 \\
\hline Mulberry fields & 36.2 & 36.7 & 39.1 & 14.6 & 15.1 & 17.6 \\
\hline Coconut plantations & 31.3 & 33.9 & - & 13.2 & 14.4 & - \\
\hline Potato plots & 32.6 & 34.4 & 34.8 & 13.9 & 14.7 & 17.0 \\
\hline Paddy fields & 34.8 & 35.4 & 36.1 & 14.1 & 15.7 & 17.4 \\
\hline Vegetable fields & 32.7 & 34.9 & 35.0 & 12.2 & 14.7 & 15.9 \\
\hline
\end{tabular}

Note: Categories of low, medium and high SOC soils are based on $<0.50 \%, 0.50-0.75 \%$ and $>0.75 \%$ Soil organic$\mathrm{C}$ respectively; Blank cells indicate that there was no representative soil sample in that categoryPNP - p-nitro phenol hydrolysed from p-nitro phenol phosphate (PNP-P)

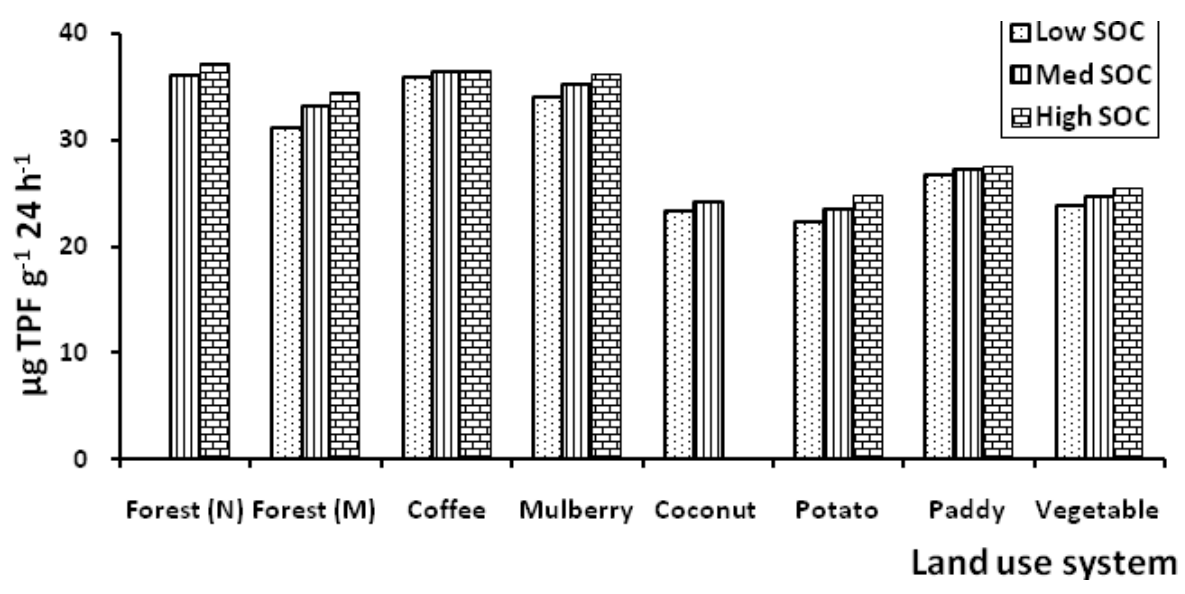

Dehydrogenase activity

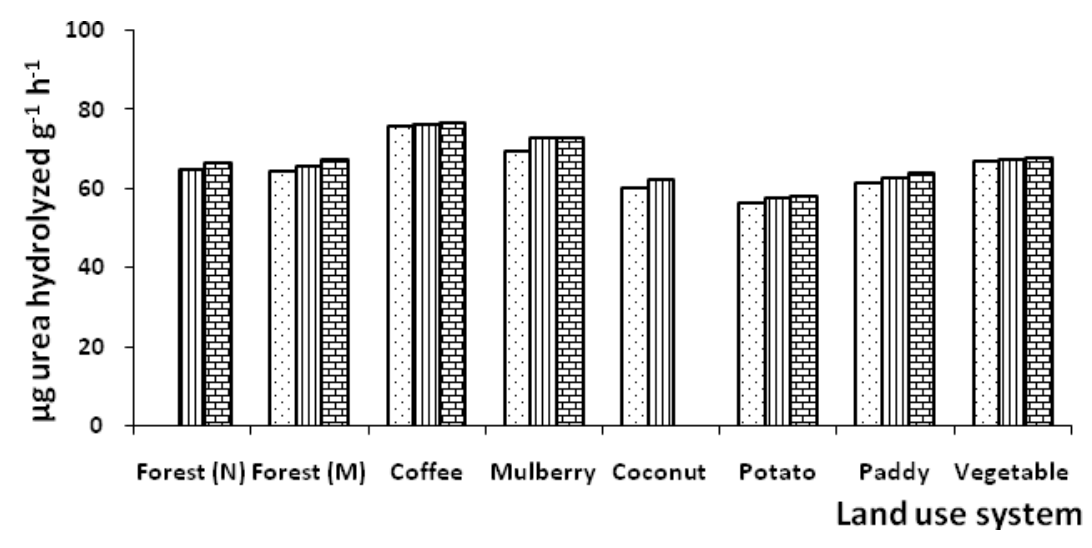

Urease activity 


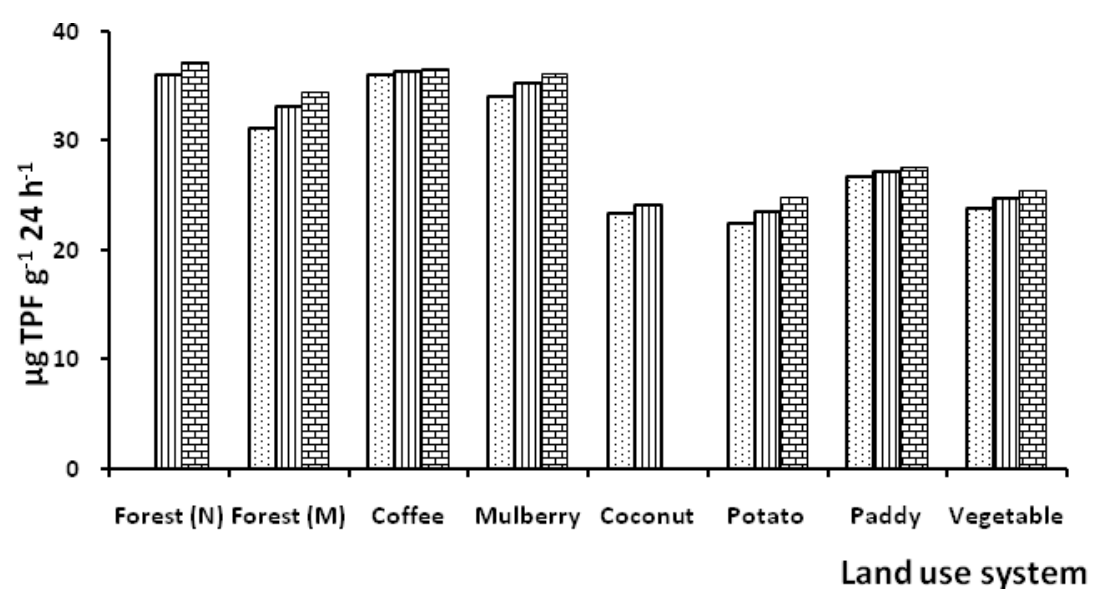

Acid phosphatase

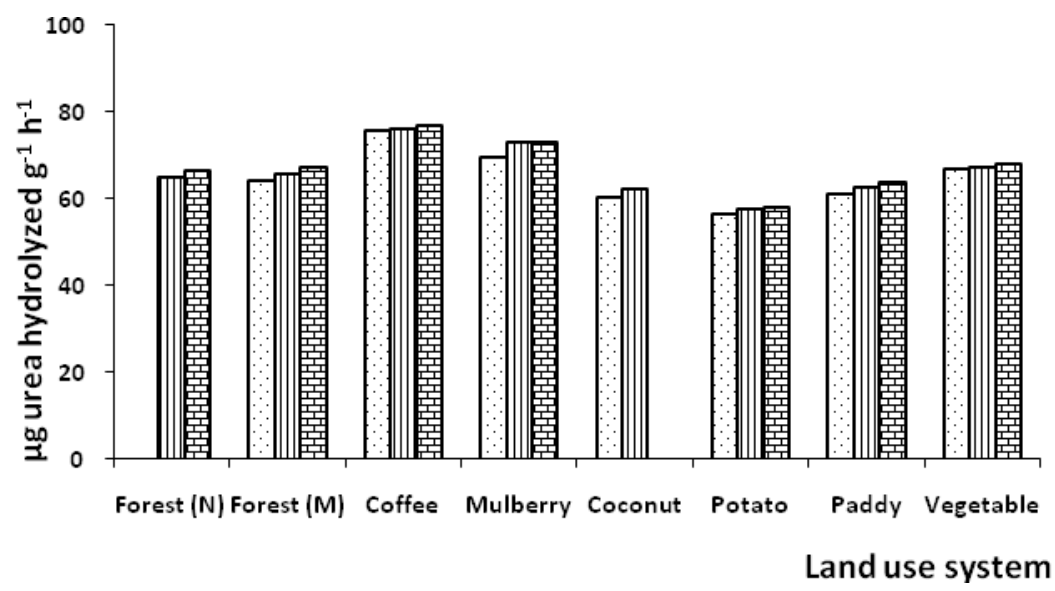

Alkaline phosphatase

Fig.1 Dehydrogenase, urease, acid and alkaline phosphatase activities in low, medium and high SOC soils of different land use system

Acid and alkaline phosphatase activity

The phosphatase activities (both acid and alkaline) was found higher in forests (natural and manmade) and coffee plantations. This can be attributed to higher soil organic matter content associated with microbial activity biomass (Rao et al., 1995). The agricultural systems generally recorded lower acid phosphatase activity (Nagaraja et al., 1997). The alkaline phosphatase activities were also higher in forests and coffee plantations, while it was lower in agricultural systems. However, mulberry recorded higher activities of both acid and alkaline phosphatase enzymes. The alkaline condition of mulberry soils might have induced alkaline phosphatase activities. Higher enzyme activity in soils with high SOC (in all land use systems) and in soils of high biomass turnover suggests that the soil organic matter management is important (Vinutha, 2005).

It was observed that the soils with high organic carbon recorded higher enzyme activities (all the four enzymes) compared to soils with low organic carbon. Thus, the enzyme activities among soils with soils with 
different levels of SOC was in the order of high $\mathrm{SOC}>$ medium $\mathrm{SOC}>$ low SOC soils.

High biomass turnover tree based land use systems recorded higher enzyme (dehydrogenase, urease and phosphatase) activities. Contrastingly, the agricultural systems supplemented with decomposed forms of organic manures recorded lesser enzyme activities. The enzyme activities among soils with different levels of SOC were in the order of high $\mathrm{SOC}>$ medium $\mathrm{SOC}>$ low SOC soils. This shows the importance of soil organic matter (SOC) serving as source of energy for soil biological activities.

\section{References}

Ajwa, H. A., Del, C. J. and Rice, C. W. 1998. Changes in enzyme activities and microbial biomass of tall grass pairie soil as related to burning and nitrogen fertilization. Soil Biol. Biochem., 31: 769-777.

Casida, L.E. Jr., Klein, D.A. and Santaro, T., 1964. Soil dehydrogenase activity. Soil Sci., 96: 371-376.

Gianfreda, L. and Bollag, J. M. 1996. Influence of natural and anthropogenic factors on enzyme activity in soil. In G. Stotzky and J.M. Bollag (ed.) Soil Biochemistry. Vol. 9. Mercel Dekker, New York, NY., pp. 123-193.

Martens, D. A., Johanson, J. B. and Frankenberger, W. T. 1992. Production and persistence of soil enzyme with repeated addition of organic residues. Soil Sci., 153: 53-61.

Monisa Raza and Tahir Ali. 2018. Labile and non-labile fractions of soil carbon under different land uses and depths in South Kashmir. The Bioscan. 13 (1):273-276.

Nagaraja, M.S., Ajay Kumar, B., and Champa, B.V. 2018. Biomass turnover interactions with soil $\mathrm{C}$ sequestration among the land uses in the Western
Ghats. Current Sci., 115(2): 213-216.

Nagaraja, M.S., Parama, V.R., Siddaramappa, R. and Rajagopal, D. 1997. The effect of pesticides on dehydrogenase, phosphatase $\&$ urease activities in some selected soils of Karnataka. J. Soil. Biol. Ecol., 17 (1): 45-53.

Pacholy, S. K. and Rice, E. L. 1973. Soil enzymes in relation to old field succession: Amylase, Invertase, Cellulase, Dehydrogenase and Urease. Amer. Soil Sci. Soc., 37: 47-50.

Rajeev Padbhushan, Rajiv Rakshit, Anupam Das and Rajendra Prasad Sharma. 2015. Assessment of long-term organic amendments effect on some sensitive indicators of carbon under subtropical climatic condition. The Bioscan. 10 (3):1237-1240.

Ranjith, M., Sridevi, S., Venkata Ramana, M. and Chandrashekhar Rao, P. 2015. Soil enzyme activity, soil microbial communities, microbial biomass carbon changes on seed cotton yield under different nutrient management practices in Bt cotton. The Bioscan. 10 (4):14991504.

Rao, C. S., Sharma, G. D. and Shukla, A. K. 1995. Spatial variation of minerals and their activity with different age groups of pine and subtropical forest soils. $J$. Boil. Ecol., 15(1): 6-16.

Siddaramappa, R. and Rao, S. R. 1971. Studies on mineralisation of urea in some soils of Mysore state. Mysore J. Agric. Sci., 5: 150-156.

Singaram, C.P. and Kamalakumari, K. 1995. Long term effect of FYM and fertilizers on enzyme dynamics of soil. J. Indian Soc. Soil Sci., 43: 378-381.

Tabatabai, M.A. and Bremer, J.M., 1969. Use of p-nitrophenyl phosphate for assay of soil phosphatase activity. Soil Biol. Biochem., 1: 301-307.

Tan, K. H. 2010. Principles of Soil Chemistry. CRC Press. Ltd., pp. 488. 
Tiwari, S.C., Tiwari, B. K. and Mishra, R.R. 1988. Enzyme activities in soils: Effects of leaching, ignition, autoclaving and fumigation. Soil Biol. Biochem., 20: 583-585.

Vaughan, D. and Malcolhm, R.E. 1985. Soil Organic Matter and Biological Activity. Junk, Baston, MA.

Vidya, K.R., Rajanna, M.D., Balakrishna Gowda and Balakrishna, A. N. 2001. Changes in enzyme activities in soils under different land uses and their seasonal variations in tropical forest soils. My Forest., 37 (3): 561-568.

Vinutha, M. C. 2005. Impact of land use types on certain beneficial soil microorganisms and their functional diversity. M.Sc. (Agri). Thesis, UAS, Bangalore.

Watts, G. W. and Crisp, J.D., 1954. Spectrophotometric method for determination of urea. Anal. Chem., 29: 554-556.

Woomer, P.L., Martin, A., Albrecht, A., Resck, D.V.S. and Scharpenseel, H.W. 1994. The importance and management of soil organic matter in the tropics. In Woomer, P.L. and Swift, M.J. (eds). The Biological Management of Tropical Soil Fertility., John Wiley and Sons, UK. pp 47-80.

\section{How to cite this article:}

Sharan Bhoopal Reddy, M. S. Nagaraja, B. C. Mallesha and Kadalli. G. G. 2020. Enzyme Activities at Varied Soil Organic Carbon Gradients under Different Land Use Systems of Hassan District in Karnataka, India. Int.J.Curr.Microbiol.App.Sci. 9(03): 1739-1745.

doi: https://doi.org/10.20546/ijcmas.2020.903.201 